\title{
PERBANDINGAN PENERAPAN KODE ETIK SYARIAH DI LEMBAGA KEUANGAN SYARIAH (STUDI PADA BANK BNI SYARIAH DAN BTN SYARIAH)
}

\section{COMPARISON OF THE APPLICATION OF SHARIA CODE OF ETHICS IN SHARIA FINANCIAL INSTITUTIONS (STUDY ON BNI SYARIAH AND BTN SYARIAH)}

\author{
Widia Yunita $^{1 \mathrm{a}}$; Andri Brawijaya ${ }^{2}$ \\ 1aProgram Studi Perbankan Syariah Fakultas Ekonomi Islam Universitas Djuanda, Jl. Tol \\ Ciawi No. 1, Kotak Pos 35 Bogor 16720, E-mail: widya.yumita.wy@gmail.com \\ 2Program Studi Perbankan Syariah Fakultas Ekonomi Islam Universitas Djuanda, Jl. Tol \\ Ciawi No. 1, Kotak Pos 35 Bogor 16720
}

\begin{abstract}
This study aims to know the application of ethics code Sharia financial institutions Sharia (lks), and see if there are differences and similarities in the application code of ethics in BNI Sharia and Bank BTN Sharia. This research method using analisiscomparative compare the same variable or sample of different. Data collection techniques using techniques interview to one of employees Islamic Bank presented of BNI Sharia and BTN Sharia. These results indicate that the ethics in lks especially in BNI Sharia and BTN Sharia have a difference and persaman in the code implementation etiknya in review of the four aspects of the ethics of general business ethics, compliance Sharia and exemplary this is because policy each Bank different and has a system code of ethics of different. However BNI Sharia and BTN Sharia have also equations on the application of ethics Sharia his where the Islamic Bank based on the principles of Sharia (Islamic).
\end{abstract}

Keywords: Islamic Financial Institutions, Islamic Banks, Comparisons, Code of Ethics.

\begin{abstract}
ABSTRAK
Penelitian ini bertujuan untuk mengetahui penerapan kode etik syariah di Lembaga Keuangan Syariah (LKS), serta mengetahui apakah ada perbedaan dan persamaan dalam penerapan kode etik di Bank BNI Syariah dan Bank BTN Syariah. Metode penelitian ini menggunakan analisis comparative membandingkan variabel yang sama atau sampel yang berbeda. Teknik pengumpulan data menggunakan teknik wawancara kepada salah satu karyawan Bank Syariah yang disajikan dari Bank BNI Syariah dan BTN Syariah. Hasil penelitian ini menunjukan bahwa etika di LKS khususnya di Bank BNI Syariah dan BTN syariah memiliki perbedaan dan persaman dalam penerapan kode etiknya di tinjau dari empat aspek yaitu etika umum, etika bisnis, kepatuhan syariah dan keteladanan hal ini dikarenakan kebijakan setiap Bank berbeda dan memiliki sistem kode etik yang berbeda. Namun bank BNI Syariah dan BTN Syariah memiliki juga persamaan pada penerapan etika syariah nya dimana Bank Syariah berlandaskan pada prinsip-prinsip Syariah (Islam).
\end{abstract}

Kata kunci : Lembaga Keuangan Syariah, Bank Syariah, Perbandingan, Kode Etik 
Widya Yunita. 2019. Perbandingan Penerapan Kode Etik Syariah di Lembaga Keuangan Syariah (Studi Pada Bank BNI Syariah dan BTN Syariah). Nisbah: Jurnal Perbankan Syariah 5 (1): 30-44.

\section{PENDAHULUAN}

Semua lembaga baik lembaga swasta maupun lembaga pemerintah memiliki kode etik yang harus mereka taati, karena kode etik tersebut sudah disepakati oleh seluruh lembaga, baik yang telah dibuat oleh pemerintah yang tercantum dalam Undang-undang dan mereka yang berkewajiban untuk melaksanakannya (Agoes, dan Cenik, 2009:13). Di eraglobalisasi saat ini, persaingan semakin ketat dan hanya mereka yang siap dan mempunyai bekal serta sikap profesionalisme yang dapat tumbuh dan bertahan. Setiap profesi dituntut untuk bekerja secara profesuinal. Kemampuan dan keahlian khusus yang dimiliki oleh suatu profesi adalah suatu keharusan agar profesi tersebut mampu bersaing didunia usaha sekarang ini. Namun, selain kemampuan dan keahlian khusus, suatu profesi harus memiliki kode etika yang merupakan aturan-aturan khusus yang harus ditaati oleh pihak yang menjalankan profesi tersebut (Muhammad, 1997:77).

Profesi tersebut tidak hanya profesi khusus tetapi termasuk profesi perbankan juga menerapkan kode etik yang wajib dipatuhi oleh semua bankir, baik itu karyawan, manajer cabang, maupun bagian lainnya. Pada dasarnya prinsip etika dalam dunia perbankan adalah kesepakatan atau indefendensi bersama dari para bankir dalam menjalankan usahanya, supaya dipercaya masyarakat dan terintegritas yang baik. (Jimly Asshidiqie, 2014:11). Menurut Martin (1993:71), etika didefinisikan sebagai "the discpline which can act as the perfomance index or refence for our control system". Dimana etika menjadi tolak ukur tindakan yang dilakukan oleh sekelompok profesi untuk kedisiplinan bekerja. Dengan demikian, etika akan memberikan semacam batasan maupun standar yang akan mengatur pergaulan manusia didalam kelompok sosialnya. (Tim Penyusun Kamus Depdikbud, 2006:103).

Bank sebagai lembaga keuangan yang terbaik di masyarakat memerlukan dukungan kinerja yang tinggi dari perilaku Sumber Daya Manusia (SDM). Bank yang integrasi, jujur dan profesional. Perbankan memegang peran penting dalam perekonomian, tentunya tidak heran jika terdapat fenomena yang sebenarnya sudah menjadi rahasia umum yang berkaitan dengan pelanggaran etika di industri perbankan seperti adanya kecurangan-kecurangan yang dilakukan oleh seorang bankir (Jusup, 2011:16) hal tersebut seharusnya tidak terjadi jika individu tersebut memahami dan menerapkan etika secara memadai dalam melakukan pekerjaan profesionalnya. Hal ini dikarenakan tindakan yang tidak etis akan merugikan banyak pihak. Oleh karena itu, diperlukan sebuah pemahaman tentang penerapan kode etik.

Dari kasus yang sudah banyak dapat disimpulkan bahwa adanya perilaku tidak etis yang dilakukan oleh seorang karyawan bank. Bisnis yang baik seharusnya bukan saja menguntungkan, namun bisnis yang baik adalah bisnis yang baik secara moral (Bertens, 2000:14). Penerapan etika perbankan di Indonesia belum berlaku secara umum masih tunduk kepada peraturan intern perusahaan bank tempatnya bekerja. Jadi penerapan kode etik disetiap bank akan mengalami perbedaan. 


\section{MATERI DAN METODE}

\section{Lembaga Keuangan Syariah (LKS)}

Lembaga keuangan syariah adalah badan usaha yang kegiatannya di bidang keuangan syariah dan asetnya berupa aset-aset keuangan maupun non keuangan berdasarkan prinsip syariah. Lembaga keuangan syariah juga dapat di artikan lembaga yang dalam aktifitasnya, baik penghimpunan dana maupun dalam penyaluran dananya memberikan dan mengenakan imbalan atau dasar prinsip syariah yaitu jual beli dan bagi hasil (Karim, Hal:32).

\section{Bank Syariah}

Bank menurut Undang-undang Nomor 7 Tahun 1992 adalah badan usaha yang menghimpun dari masyarakat dalam bentuk simpanan dan menyalurkannya kepada masyarakat dalam rangka meningkatkan taraf hidup rakyat banyak. Suatu lembaga yang menghimpun dana dari masyarakat dan menyalurkan kembali kepada masyarakat, dalam literatur Islami dikenal dengan istilah baitul mal atau baitul tamwil. Istilah lain yang digunakan untuk Bank Islam adalah Bank Syariah. Secara akademik istilah Islam dan Syariah berbeda, namun secara teknis untuk penyebutan bank Islam dan Bank Syariah mempunyai pengertian yang sama. (Antonio:6)

\section{Kode Etik Syariah}

Etika dalam bahasa latin "ethica" yang berarti falsafah moral. Etika merupakan pedoman cara bertingkah laku yang baik dari sudut pandang budaya, susila, serta agama (Martandi dan Suranta, 2006) sedangkan menurut (Bartens, 2007) adalah kumpulan asas atau nilai moral yang menjadi pedoman bagi seseorang atau suatu kelompok dalam mengatur tingkah lakunya, sehingga dapat diartikan bahwa etika merupakan ilmu tentang apa yang baik dan apa yang buruk dan tentang hak dan kewajiban moral (akhlak).
Dalam bahasa Arab, "Etika Islam" biasa disepadankan dengan beberapa istilah yaitu falsafah al-akhlaq dan al$a d a b$. Dimana istilah akhlaq merupakan kata kunci dalam membahas masalah etika Islam, karena istilah akhlaq lebih dikenal dalam pembahasan masalah etika dalam Islam dan bentuk mufradnya "khuluq" secara langsung tercantum didalam teks Al-Qur'an maupun Hadits Nabi (Shaliba, 2002:1). dan adab yang berarti kebiasaan atau adat, sebagaimana kata Toha Husain, bahwa kata adab berasal dari kata "al-da-bu" yang berarti "al-adah" (Al-Jabiri, 2001:42). Selain itu, arti kata $a d a b$ dengan kesopanan, pendidikan dan akhlaq (A.W. Munawari:13-14). Dengan demikian kata $a d a b$ juga dapat berarti etika.

Tujuan pokok mengenai etika adalah mempengaruhi dan mendorong kehendak kita supaya mengarah kepada yang berfaedah dan berguna bagi sesama manusia. Karena obyek kajian dalam tulisan ini adalah perbankan syariah, maka Ethical Climate Theory dari Bart Victor dan John B. Cullen, akan disandangkan dengan tiga prinsip utama nilai-nilai Islam yang dijadikan sebagai landasan filosofi bagi perbank syariah (Gemala Dewi, 2005:37). Terdiri dari:

a. Kejujuran (Honesty, Ash-Shidiq)

Kejujuran merupakan hal yang harus dilakukan oleh setiap manusia dalam berbagai segi kehidupan termasuk dalam bermuamalah, kejujuran menjadi bukti adanya komitmen akan pentingnya perkataan yang benar sehingga dapat dijadikan pegangan, hal ini akan memberikan manfaat bagi para pihak yang melakukan akad (perikatan) dan juga bagi masyarakat dan lingkungannya. Perintah ini sesuai dengan Firman Allah SWT dalam Qs. Al-Ahzab(33) ayat:70 


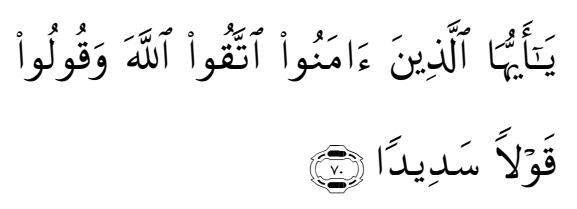

Artinya: "Hai orang-orang yang beriman, bertaqwalah kamu kepada Allah, dan katakanlah perkataan yang benar"

Nilai ini memastikan bahwa pengelolaan bank syariah wajib dilakukan dengan moralitas tang menjungjung tinggi kejujuran. Dengan demikian kejujuran merupakan nilai moral yang mendasar untuk menggapai ridha Allah dalam praktek perbankan syariah.

b. Kesetaraan, Faithful (Al-Musawah)

Adanya kesamaan untuk saling mempercayai yang dituangkan dalam suatu akad menjadi faktor penentuan bagi kesuksesan masing-masing pihak yang terkait dengan hak dan kewajiban sehingga tidak saling merugikan keuntungan/kelebihan kepada yang lain, ada kesediaan membentuk sesama dan mau bekerja sama.

c. Keadilan dan Kebenaran (Justice and Equity, Al-Adialah)

Setiap akad (Transaksi) harus benar-benar memperhatikan rasa keadilan dan sedapat mungkin menghindari perasaan tidak adil (Dzalim), oleh karenanya harus ada saling ridha dari masing-masing pihak. Kita tidak diperkenankan memakan harta orang lain dengan cara yang batil, kecuali dengan jalan jual beli sehingga ridha.

\section{Etika Bisnis}

Etika bisnis ialah kaidah-kaidah peraturan yang diterapkan dan diterima oleh seluruh anggota suatu profesi. Kode etik harus dilaksanakan dengan baik dan tidak boleh menyimpang dari peraturanperaturannya dapat dipecat dari profesinya (Simongkar :87) Kedudukan kode etik adalah sebagai pedoman untuk berprilaku yang baik dan benar, namun implementasinya sangat tergantung kepada karakter masing-masing individu. Sedangkan tujuan kode etik sendiri yaitu untuk memecahkan sekaligus untuk menyempurnakan perilaku menyimpang dari pada nilai-nilai luhur yang ada pada manusia dalam kelompoknya.

\section{Kepatuhan Syariah}

Kepatuhan syariah merupakan syarat mutlak yang harus dipenuhi oleh lembaga keuangan yang menjalankan kegiatan usaha, berdasarkan prinsip syariah. Kepatuhan syariah adalah pemenuhan seluruh prinsip syariah dalam semua kegiatan yang dilakukan sebagai wujud dari karakteristik lembaga tersebut. Kepatuhan syariah itu bagian dari pelaksanaan framework manajemen risiko yang memiliki standar internasional yang disusun dan ditetapkan oleh Islamic Financial Service Board (IFSB) dimana kepatuhan syariah merupakan bagian dari tata kelola lembaga, (Ilhami, 2009:409).

\section{Keteladanan}

Pada dasarnya, kebutuhan manusia akan figur teladan bersumber dari kecenderungan meniru yang sudah menjadi karakter manusia. Imitasi adalah peniruan (pengkopian) perilaku, yaitu meniru perilaku seseorang, dimana perilaku orang yang ditiru tersebut perupakan suatu pola (Hamzah, 2006:194). Peniruan bersumber dari kondisi mental seseorang yang senantiasa merasa bahwa dirinya berada dalam perasaan yang sama dengan kelompok lain (empati). Sehingga dalam peniruan ini, bawahaan cenderung meniru atasannya (Abdurrahman, 1995: 263).

$\begin{array}{crr}\text { Teknik } & \text { pemeberian } & \text { teladan } \\ \text { kepemimpinan } & \text { menurut } & \text { Syafi'ie }\end{array}$ (2003:45) adalah stategi atau cara yang dilakukan oleh pemimpin melalui pemberian keteladanan atau contoh kepada bawahaan atau pegawai. Dari definisi tersebut dapat dipahami bahwa 
teknik keteladanan merupakan upaya atau cara yang dilakukan oleh pemimpin dengan tujuan agar pegawai dapat lebih disiplin dan meningkatkan kinerjanya. Untuk terciptanya tujuan itu, intansi yang bertanggung jawab atas kepatuhan atau kedisiplinan bawahannya harus mampu memberikan motivasi yang baik (Syafi'ie, 2003:45).

\section{Metode Penelitian}

Jenis penelitian ini kualitatif, yaitu suatu pendekatan atau penelusuran untuk mengekporasi dan memahami suatu keadaan, kejadian atau fenomena yang terjadi. Cara yang dilakukan adalah dengan wawancara, observasi, atau menggunakan kuesioner kepada partisipan (informasi yang berasal dari sumber penelitian). Informasi yang dapat disampaikan dan didapatkan oleh partisipan selanjutnya dianalisis, hasil analisis tersebut dapat berupa penggambaran atau deskripsi, dan melakukan interperstasi untuk mendapatkan hasil yang mendalam. (Conny, 2017: 7-8)

Penelitian ini menggunakan metode descriptive comparative yaitu membandingkan variabel yang sama atau sampel yang berbeda. komparatif deskriptif juga dapat digunakan untuk membandingkan variabel yang berbeda untuk sampel yang sama. Menurut Sulistyo-Basuki penelitian komparatif merupakan metode penelitian yang membandingkan tentang benda, orang dan hal-hal lain dengan cara menganalisis persamaan dan perbedaan yang ada dari objek atau subjek yang diteliti (Sulistyo, dan Basuki, 2006: 114). Dengan sumber data sebagai berikut:

a. Data Primer

Yaitu data yang dicari,
dilaksanakan, diambil dan diolah
sendiri oleh peneliti serta didapat dari
suatu organisasi atau lembaga melalui
objeknya (Kuswadi, 2004; Wadiah,
2015). Sumber data primer ini
diperoleh dengan cara mencari data

dan informasi melalui wawancara langsung (interview) dengan pihak Bank BNI Syariah dan Bank BTN Syariah

b. Data Sekunder

Catatan tentang adanya suatu peristiwa ataupun catatan-catatan yang jaraknya telah jauh dari sumber orisinil. Sumber data sekunder yang diperoleh berasal dari internet, buku, jurnal skripsi, thesis dan literatur lainnya yang terkait ke dalam penelitian ini (Nazir, 2014: 39).

Teknik pengumpulan data pada penelitian ini yaitu:

a. Wawancara atau Interview

Wawancara ini dilakukan secara langsung kepada Back Officer Head Bank BNI Syariah dan Human Capital Division Bank BTN Syariah.

b. Observasi

Adalah pengamatan langsung dilapangan dan dengan teknik ini data didapat dengan cara survei langsung ke kantor BNI Syariah dan BTN Syariah. Teknik ini biasa digunakan untuk mengumpulkan data-data secara jelas dengan cara melakukan pengamatan dan perincian yang sistematis tentang hal-hal yang berhubungan dengan tema penelitian (Ghany, 2015).

c. Dokumentasi

Objek dokumen yang digunakan pada penelitian ini yaitu jurnal atau literatur yang berkaitan dengan kode etik, laporan tahunan, surat edaran direksi dan foto-foto kegiatan wawancara. Hal ini digunakan untuk membuktikan kebenaran segala sesuatu yang berkaitan dengan kegiatan, serta dapat digunakan untuk menunjang hasil wawancara. (Sugiyono, 2013:326)

Penelitian ini menggunakan teknik analisis komparatif yaitu penelitian deskripsi yang sifatnya membandingkan. mencangkup transkip hasil wawancara, reduksi data, analisis, interperstasi data 
dan triangulasi. Dari analisis data yang kemudian dapat ditarik kesimpulan. (Sugiyono, 2010). Aktifitas dalam analisis data yaitu Collection (mengumpulkan data), Reduction (mereduksi data), Display (Penyajian Data) dan terakhir Penarikan Kesimpulan (Conclusions Drawing).

\section{HASIL DAN PEMBAHASAN}

\section{Kode etik Bank BNI Syariah dan Bank BTN Syariah}

Kode etik insan BNI Syariah merupakan norma, pedoman, dan aturan yang dimiliki oleh BNI Syariah yang menjadi landasan dalam berperilaku bagi setiap insan BNI Syariah. (1) menjalankan kegiatan usaha berdasarkan prinsip syariah, secara kaffah dan istiqomah, (2) menjalankan kegiatan usaha yang dapat memberikan kemaslahatan (maslahah) dan berlaku universal, (3) melakukan pencatatan data dan penyusunan laporan BNI Syariah dengan baik dan benar, (4) larangan penyalahgunaan jabatan, (5) menghindari benturan kepentingan, (6) tidak melakukan penyuapan atau menerima dan/atau memberikan imbalan dan cinderamata (Risywah), (7) menjaga nama baik BNI Syariah, (8) menjaga kerahasiaan bank, (9) penggunaan corporate identity, (10) kompetensi, (11) menjadi panutan, (12) adil, (13) pengungkapan informasi, (14) menjaga hubungan baik (ukhuwah) antara insan BNI Syariah, (15) pekerjaan menjadi pembicara, (16) sumbangan dan keikutsertaan dalam partai politik, (17) menjaga keamanan kerja dan kebersihan lingkungan kerja, (18) menjaga dan menggunakan aset BNI Syariah dengan benar dan penuh tanggung jawab, (19) Komitmen terhadap lingkungan dan kepedulian sosial.

Kode etik Bank BTN Syariah yaitu (1) patuh dan taat pada ketentuan syariah serta perundang-undangan dan peraturan yang berlaku, (2) melakukan pencatatan segala transaksi yang berhubungan dengan kegiatan Bank BTN secara benar sebagai wujud dari profesinalisme dan sikap amanah, (3) berlomba-lomba dalam kebaikan untuk memberikan yang terbaik kepada seluruh stakeholder, (4) tidak menyalahgunakan wewenangnya untuk kegiatan pribadi, (5) nenghindarkan diri dari keterlibatan dalam pengembalian keputusan dalam hal terdapat petentangan kepentingan, (6) menjaga kerahasiaan nasabah dan Bank BTN Syariah, (7) memperhitungkan dampak yang merugikan dari setiap kebijakan yang ditetapkan Bank BTN terhadap keadaan ekonomi, sosial dan lingkungannya, (8) tidak menerima hadiah atau imbalan yang memperkaya diri sendiri maupun keluarga

perbandingan dan persamaan antara kode etik Bank BNI Syariah dengan Bank BTN Syariah ditinjau dari penerapannya. Deskripsi jawaban dari responden yang penulis teliti terbagi menjadi empat yaitu perbandingan dan persamaan penerapan etika umum di Bank BNI Syariah dan BTN Syariah, etika bisnis di Bank BNI Syariah dan BTN Syariah, kepatuhan syariah di Bank BNI Syariah dan BTN Syariah dan keteladanan di Bank BNI Syariah dan BTN Syariah.

\section{Perbandingan Penerapan Etika Umum}

1. Persamaan Antara Bank BNI Syariah dan BTN Syariah

Pertama, pada penerapan etika profesi Etika yang diterapkan di BNI Syariah sudah sesuai dengan karakter karyawannya karena kode etik itu dibentuk untuk membentuk karakter karyawan itu sendiri, BNI Syariah sebagai perusahaan Syariah menginginkan karakter pegawai nya sesuai dengan Syariah, dimana sesuai Syariah itu yang berlandaskan AlQur'an dan Hadits. Sama halnya dengan Bank BTN Syariah etika yang 
diterapkan di BTN Syariah sudah sesuai dengan karakter karyawannya karena karyawan di BTN Syariah ratarata memiliki karakter agama yang kuat sehingga terjadi keselarasan anatara pekerjaan dan kepribadian masing-masing.

Kedua, di Bank BNI Syariah yang sudah sesuai dengan prinsip syariah. Salah satu nya dilihat dari point-point etika BNI Syariah seperti adil, kompeten, menjalankan kegiatan usaha berdasarkan prinsip syariah. Menjalankan kegiatan usaha yang dapat memberikan kemaslahatan (maslahah) jadi di point ini tentang kemasalahatan ummat tidak hanya mecari keuntungan. Sama halnya di Bank BTN Syariah penerapannya sudah sesuai dengan prinsip syariah, dimana prinsip-prinsip Syariah yang utamanya adalah berlaku jujur terhadap nasabah, dan menyelesaikan setiap permasalahan yang ada dengan prinsip musyawarah. Selain itu karakter dari para pegawainya pun sangat kental akan unsur keagamaan, para pegawai dapat menjaga amanah dan menjalankan tugas dengan disiplin yang baik.

Ketiga, pada penerapan etika yang bernilai syariah bank BNI Syariah berpendapat bahwa kode etik yang bernilai syariah penerapannya tidak ada perbedaan (sama), hanya saja yang dapat membedakan label namanya saja. Begitu pula bank BTN Syariah berpendapat bahwa kode etik yang bernilai syariah penerapannya sama karena Secara realita prinsip syariah yang digunakan sama-sama berlandaskan pada Fatwa yang dikeluarkan oleh Lembaga Keungan Syariah di Indonesia

Keempat, respon bankir pada penerapan etika, di BNI Syariah Penerapan kode etik dapat diterima oleh semua bankir, selama kita bekerja dan dikontrak oleh seuatu perusahaan kita harus menerima semua peraturan dan kode etik. Sama halnya di BNI Syariah Tentu dapat diterima oleh semua bankir, sampai sejauh ini tidak pernah ada pegawai BTN Syariah Bogor yang terindikasi maupun terlibat dalam tindakan pelanggaran kode etik.

2. Perbedaan Antara Bank BNI Syariah dan BTN Syariah

Pertama, pada pendapat responden mengenai kode etik, Bank BNI Syariah berpendapat bahwa Kode etik yaitu tentang standar etik disetiap profesi atau perusahaan termasuk di perbankan juga mempunyai kode etik. Oleh karena itu etika digunakan sebagai panduan atau acuan etika si profesi itu sendiri untuk menjalankan profesi nya yang ditekuni. Sedangkan Bank BTN Syariah berpendapat bahwa Kode etik yaitu pedoman-pedoman terkait dengan cara melakukan pekerjaan, hak dan kewajiban pegawai, serta larangan-larangan pegawai yang ada dalam peraturan internal Bank seperti pada Ketentuan Direksi (KD), Surat Edaran Direksi (SE), dan Standar Operasional Prosedur (SOP).

Kedua, pada penerapan kode etik BNI Syariah di sebut dengan Kode Etik Insan BNI Syariah, yang merupakan norma, pedoman dan aturan yang dimiliki oleh BNI Syariah yang menjadi landasan dalam berperilaku bagi setiap Insan BNI Syariah. Segenap insan BNI Syariah diharuskan untuk mematuhi dan menerapkan setiap point dari Etika Insan BNI Syariah sesuai dengan SE Direksi No. BNISy/DIR.403 tanggal 23 Desember 2010. BNI Syariah mempunyai sembilan belas Kode Etik yang menjadi norma, pedoman dan aturan bagi setiap insan BNI Syariah. Sedangkan Bank BTN memiliki delapan point kode etik pada penerapannya, dan sudah berjalan 
dengan baik, hubungan antara pegawai dengan sesama rekan kerja maupun antara pegawai dengan nasabah dan pihak kedua lainnya berjalan dengan baik dan tidak ditemui masalah apapun, terbukti pada tahun 2017 lalu BTN Syariah Bogor mendapatkan peringkat satu di regional satu dalam hal pemberian layanan terbaik. Selain itu dalam test yang sering diadakan oleh kantor pusat BTN (Test Anti-Fraud dan Gratifikasi) BTN Syariah Bogor juga ikut serta dan mendapat nilai diatas rata-rata.

Ketiga, perbandingan pada nilai etika syariah BNI Syariah yaitu Ukhuwah antara karyawan bank apalagi bank BNI Syariah ini tidak memperbolehkan karyawan laki-laki dan perempuan untuk mengobrol diluar kerja melebihi kewajaran. Sedangkan BTN Syariah memiliki nilai kode etik syariah yang dapat membandingan BTN Syariah dengan Bank Syariah lain yaitu Kode etik di bank BTN Syariah diperkuat oleh budaya kerja di Bank BTN Syariah yaitu SIIPS, yang mana budaya kerja tersebut berbeda dengan budaya kerja dibank lain. Bank BTN Syariah mengutamakan sinergi, integritas, inovasi, profesionalisme dan spirit dalam mencapai keunggulan yang dampaknya saat ini posisi bank BTN Syariah sudah masuk lima besar bank dengan aset terbesar di Indonesia.

Keempat pada pendapat responden mengenai etik profesi Bank BNI Syariah berpendapat bahwa etik profesi yaitu diharuskan ada disetiap bank karena untuk membatasi sikap atau etika pegawai agar tidak keluar dari jalur yang semestinya. Sedangkan Bank BTN Syariah berpendapat etika profesi yaitu Kode etik seorang bankir di bank syariah tidak jauh berbeda dengan bankir di Bank Konvensional, hanya saja dalam melakasanakan pekerjaan seorang bankir syariah tidak hanya bertindak berdasarkan aturan-aturan internal tetapi juga bertindak berdasarkan prinsip-prinsip syariah yang terdapat pada al-Quran, Hadis, dan fatwa-fatwa yang berlaku.

Kelima, keefektifan dari penerapan etika di Bank BNI Syariah sudah berjalan cukup efektif karena kode etik BNI Syariah terutama dikantor pusat dihafal, sehingga paling tidak pegawai tahu mengenai kode etik BNI Syariah yang nantinya akan diterapkan di pegawai masing-masing dan dijalankan. Sedangkan Bank BTN Syariah sudah sangat efektif, karena sampai saat ini kode etik yang ada dapat diterima oleh pegawai dan tidak memicu terjadinya kesalahpahaman anatara kode etik yang ada dengan realita dilapangan.

Keenam, kurangnya pemahaman terkait masih banyaknya pelanggaran, BNI Syariah berpendapat masih banyak nya pelanggaran dikarenakan faktor-faktor yang menyimpang, yaitu salah satunya ketidak tahu atau tidak hafal etika BNI Syariah, kurang nya sosialisasi dari pimpinan, dan faktor lingkungan karena faktor lingkunganlah yang sangat mempengaruhi, walaupun mereka sudah tahu mengenai etika tetapi lingkungannya (pergaulan) mendukung untuk melanggar kode etik. Sedangkan BTN Syariah berpendapat bahwa masih banyaknya pelanggaran yaitu, Pertama kurangnya pemahaman pegawai tentang peraturan atau etika itu sendiri, hal ini dikarenakan pegawai tersebut tidak pernah mendapatkan informasi terkait kode etik tersebut dan tidak pernah mau mempelajari kode etik yang ada sehingga dia bekerja sesuai dengan kehendaknya sendiri. Kedua adalah pengaruh lingkungan, lingkungan kerja atau teman kerja biasanya memiliki pengaruh terhadap 
tindakan seorang pegawai terutama sifat dan perilaku dalam bekerja. Jika lingkungan tempat pegawai bekerja sudah terbiasa melakukan pelanggaran kode etik dampaknya terhadap pegawai tersebut menjadi terbawa untuk melakukan pelanggaran juga dan akhirnya hal tersebut menjadi hal yang biasa untuk dilakukan. Ketiga terkait dengan kepribadian pegawai itu sendiri, perlu diketahui mengubah watak seseorang bukanlah hal yang mudah, jika dari awal pegawai tersebut sudah memiliki watak yang menjurus terhadap pelanggaran kode etik.

Ketujuh, pada pengawasan yang dilakukan. BNI Syariah melakukan pengawasan Bank terhadap etika yang diterapkan yaitu adanya audit internal yang pasti mengawasi jika ada penyelewengan atau penyimpangan yang dilakukan oleh karyawan, dan langsung dilakukan pemeriksaan lebih lanjut. Tim audit pun melakukan tugas nya seperti pencegahan, ceklis dan/atau uji kepatuhan, dan ceklis ini dilakukan ketika pagi sebelum dimulainya jam kerja. Sedangkan Terkait dengan pengawasan pelaksanaan kode etik di Bank BTN Syariaah (Kantor Pusat) membentuk tim yang terdiri dari 3 Divisi yaitu Human Capital Division, Compliance Division dan Internal Audit Division, dimana ketiga divisi tersebut bekerja sama melakukan monitoring dan juga melakukan mitigasi agar tidak terjadi pelanggaran kode etik. Terutama dari Compliance Division yang rutin melakukan langkah mitigasi dengan melakukan SMS Blast dan Email Blast himbauan untuk tidak melakukan pelanggaran-pelanggaran yang berakibat kerugian pihak Bank, pihak lain maupun diri sendiri dan keluarga. Untuk pengawasan lebih lanjut Compliance Division bekerja sama dengan Human Capital Division juga rutin melakukan serangkaian test untuk menguji tingkat kedisiplinan pegawainya. Dari bagian Internal Audit Division juga melakukan monitoring langsung kelapangan minimal satu tahun sekali untuk melakukan survey langsung pada pegawai-pegawai dikantor cabang.

\section{Perbandingan Penerapan Etika Bisnis}

1. Persamaan Antara Bank BNI Syariah dan BTN Syariah

Pertama, Bank BNI Syariah menerapkan etika bisnis dalam menjalankan bisnisnya karena untuk mencapai suatu tujuan bank harus berjalan dengan semestinya, dasarnya dari Buku Panduan Pegawai. Ketika bank menjalankan etika bisnis yaitu tujuan nya satu. untuk mencapai bisnis tentunya bank membutuhkan yang pertama startegi yang bagus, sesuai dengan etika atau dengan peraturan yang ada. Sama halnya dengan Bank BNI Syariah, Bank BTN Syariah pun menerapkan etika bisnis dalam menjalankan bisnisnya karena dalam bisnis etika sangat diperlukan oleh semua pengusaha, tujuannya untuk mendorong kesadaran moral dan memberikan batasan-batasan bagi para pengusaha atau pelaku bisnis untuk menjalankan Good business dan tidak melakukan Monkey business atau Dirty business. Dimana hal itu dapat merugikan banyak pihak yang terkait. Selain itu dengan etika bisnis, para pelaku bisnis memiliki aturan yang dapat mengarahkan dalam mewujudkan citra dan manajemen bisnis yang baik, sehingga dapat dipercaya oleh masyarakat.

Kedua, Penerapan etika bisnis Bank BNI Syariah sudah sesuai dengan prinsip syariah tapi belum sempurna, karena masyarakat Indonesia belum semuanya memahami prinsip syariah dan siap dengan metode prinsip syariah keseluruhan. Begitu pun BTN Syariah penerapan etika bisnis nya 
sudah sesuai dengan syariah karena prinsip dasar bank BTN Syariah bersasarkan prinsip-prinsip Syariah dan budaya kerja Bank. Hanya saja sebagai standar perilaku pegawai dan etika bisnis Bank, etika selalu menjadi bagian dalam hidup masyarakat secara luas. Etis tidaknya suatu perilaku sangat tergantung dari standar persepsi masyarakat sekitarnya.

Ketiga, permasalahan yang sering terjadi dalam penerapan etika bisnis di Bank BNI Syariah adalah belum siapnya nasabah menerima bisnis dengan menggunakan prinsip-prinsip syariah. Begitupun di Bank BTN Sayariah adalah persepsi masyarakat sekitarnya. Dengan demikian masalah etika sangat erat hubungannya dengan persepsi sosial dari kondisi dimana perilaku tersebut dilakukan.

Keempat, begitu munculnya permasalahan Bank BNI Syariah dan BTN Syariah memiliki strategi untuk mengatasinya, dimana Bank BNI Syariah Syariah dalam mengatasi masalah tersebut adalah memperbanyak mengenali produkproduk syariah, mengenali hukumhukum syariah, bahwasannya bank syariah dengan dakwah first bisnis follow. Bank BTN pun memiliki strategi yang sama yaitu memberikan pemahaman mengenai akad-akad kepada masyarakat, membangun kerjasama yang sinergis dengan seluruh stakholder dengan menghindari terjadinya gratifikasi.

2. Perbedaan Antara Bank BNI Syariah dan BTN Syariah

Pertama, pada pendapat responden mengenai etik bisnis, Bank BNI Syariah berpendapat bahwa etik yaitu etika bisnis di BNI Syariah Sudah berjalan dengan baik, karena kegiatan usahannya berdasarkan Buku Pedoman Pegawai (BPP), jadi etika bisnis yang ada di BNI Syariah sudah berjalan dengan semestinya. Sedangkan Bank BTN Syariah berpendapat bahwa etika bisnis yaitu pedoman yang menjelaskan etika usaha dan tata perilaku insan Bank BTN Syariah untuk melaksanakan praktek-praktek pengelolaan perusahaan agar menjadi lebih baik. Terutama dengan adanya etika bisnis ini hubungan karyawan atau pihak Bank BTN Syariah dengan pemangku kepentingan (Stakholder), dan masyarakat terjalin dengan baik.

Kedua, pada keunggulan etika bisnis, Bank BNI Syariah memiliki keunggulan dalam penerapan bisnis yaitu dengan menjalankan prinsipprinsip agama yang diladasi syariah agama. Salah satunya menjadi bank yang pelayanan nya good servis, yaitu pelayanan yang melebihi ekspektasi harapan nasabah. BNI Syariah ini melakukan pemeliharaan terus dengan nasabah, menjaga hubungan baik dengan nasabah (ukhuwah), misalkan ketika nasabah milad kita silaturahmi ke rumahnya agar hubungan baik tetap terjaga dan bisnis tetap berjalan dengan baik. Sedangkan keunggulan penerapan etika bisnis di BTN Syariah adalah loyal community pada perumahanperumahan yang dibiayai oleh bank BTN Syariah dan bertauhid. Dimana suatu bentuk sikap atau tindakan yang berpedoman dan sesuai dengan tuntunan agama islam, sehingga dengan menerapkan tauhid dalam bisnis bertujuan untuk menciptakan kegiatan yang tidak hanya berdasarkan mencari keuntungan semata namun yang lebih penting adalah untuk bertindak sesuai dengan aturan norma agama. 


\section{Perbandingan Penerapan Kepatuhan Syariah}

1. Persamaan Antara Bank BNI Syariah dan BTN Syariah

Pertama, kepatuhan syariah di BNI Syariah dan BTN Syariah sudah sesuai. di BNI Syariah Sudah mematuhi peraturan dan sudah mematuhi prinsip-prinsip syariah. Begitupun di BTN Syariah sudah sesuai karena jika belum mematuhi syariah dilihat dalam jangka panjang, tentu saja hal ini akan merugikan gerakan ekonomi syariah dan industri perbankan syariah secara keseluruhan. sehingga, konsistensi untuk mematuhi prinsip syariah harus menjadi ruh bagi setiap pelaku industri keuangan syariah.

Kedua, Bank BNI Syariah dan BTN Syariah berpendapat bahwa memiliki sikap kepatuhan syariah yang sama. BNI Syariah berpendapat jika dilihat dari tiga prinsip yaitu prinsip syariah, agama dan ukhuwah Islamiah, kepatuhan Syariahnya sama saja. Begitupun Bank BTN Syariah berpendapat hal yang sama dimana semua Bank Syariah berpegang teguh kepada prinsip-prinsip Islam yaitu seperti tingkat kepatuhan dalam mengelola bisnis bagi hasil. Hanya saja yang dapat membandingkan nya itu tingkat kepatuhannya. Contoh tingkat kepatuhan di Indonesia dalam penerapan prinsip bagi hasil mencapai $38 \%$ dari ketentuan-ketentuan syariah. Sedangkan dimalaysia tingkat kepatuhannya hanya 8\%.

Ketiga, Kepatuhan syariah BNI Syariah ditunjukan untuk meningkatkan kualitas SDM karena kepatuhan itu sendiri membentuk karakter SDMnya. Dan kepatuhan SDM BNI Syariah sangat berpengaruh terhadap kehidupan, pekerjaan, dan dalam menjalankan prinsip-prinsip syariah kesehariannya. Dan Kepatuhan syariah BTN Syariah pun ditunjukan untuk meningkatkan kualitas SDM karena sasaran dari fungsi kepatuhan itu adalah mendukung kinerja Bank BTN Syariah menjadi lebih baik dan perilaku SDM yang ada dapat meningkatkan produktivitas kerja untuk menghadapi berbagai tantangan dimasa yang akan datang. Seperti Start from the top yaitu kepatuhan akan efektif penerapannya jika terdapat kesungguhan dan komitmen tinggi dari manajemen puncak (direksi dan komisaris), keberadaan kebijakan dan prosedur kepatuhan yang telah ditetapkan harus diupayakan semaksimal mungkin oleh seluruh jajaran manajemen sesuai dengan tugas, tanggung jawab dan wewenangnya masing-masing.

2. Perbedaan Antara Bank BNI Syariah dan BTN Syariah

Pertama, pada pendapat responden mengenai kepatuhan syariah, Bank BNI Syariah berpendapat bahwa kepatuhan syariah di BNI Syariah sudah berjalan dengan baik karena diawasi oleh DPS yaitu Dewan Pengawasan Syariah, walaupun DPS ini hanya berfokus kepada produk saja tetapi Bank Syariah bisa mendiskusikan mengenai peraturan ataupun kode etik, kepatuhan dan lain sebagainya. Sedangkan bank BTN Syariah berpendapat bahwa kepatuhan Bank BTN Syariah mengacu kepada ketentuan BI (PBI No.13/2/PBI/2011) dimana kebijakan yang dikeluarkan oleh Bank Indonesia mencangkup penyempurnaan dari segi organisasi di perbankan, tugas dan tanggung jawab semua pihak yang terkait dalam pelaksanaan fungsi kepatuhan, sesuai dengan kerangka manajemen risiko, dalam mendukung terciptanya budaya kepatuhan. Berdasarkan pada peraturan tersebut direktur kepatuhan BTN telah melaksanakan tugasnya seperti menyusun rencana kerja kepatuhan 
yang dimuat dalam rencana bisnis Bank guna mendorong dan/atau memelihara budaya kepatuhan.

Kedua, budaya yang mendukung kepatuhan, di BNI Syariah adalah menjaga tali silaturahmi dan ukhuwah Islamiah antara pegawai, dan terutama mendekatkan diri kepada Allah SWT. Sedangkan budaya di BTN Syariah yaitu membentuk budaya yang sama. Budaya yang sama maksudnya adalah sebuah pola pikir yang membuat mereka memiliki persepsi yang sama tentang nilai, dan kepercayaan yang dapat membantu mereka untuk memahami tentang bagaimana seharusnya berperilaku dalam bekerja pada perusahaan dimana mereka bekerja sekarang. Adapun nilai-nilai budaya kerja bank BTN Syariah pada umumnya berdasarkan kepada lima pilar utama yaitu: Transparency, Responsibility, Accountability, Fairness, dan Independency. Kelima unsur ini dilakukan sehingga membentuk budaya kerja yang islami, sebagaimana dikemukakan oleh Umer Chapra bahwa stakholders utama keuangan Islam adalah Islam itu sendiri.

\section{Perbandingan dan Persamaan \\ Penerapan Keteladanan}

1. Persamaan Antara BNI Syariah dan BTN Syariah

Pertama, pada pendapat responden mengenai keteladanan, Bank BNI Syariah berpendapat bahwa keteladanan syariah di BNI Syariah Sudah berjalan dengan baik dengan adanya regenerasi. Regenerasi yaitu mencontohkan dengan baik dan bisa diikuti oleh bawahannya, contohnya sebagai seorang pemimpin harus menjadi contoh teladan, dengan caranya menjalankan prinsip syariah, berkomunikasi dan dengan cara menangani masalah, karena sebagai pemimpin ini bukan tentang teknis tetapi memanage people. BTN Syariah pun berpendapat sama yaitu keteladanannya sudah baik, dimana keteladanan itu perbuatan atau sifat seorang pemimpin yang dijadikan contoh bagi karyawannya (uswatun hasanah), dan Bank BTN Syariah menjungjung tinggi nilai akan sebuah layanan prima, penuh dengan inovasi, menjadi teladan dalam bekerja, dilandasi jiwa profesionalisme, memegang teguh integritas dan saling bekejasama.

Kedua, pada pemicu keteladanan di BNI Syariah mengacu kepada kedisiplinan pemimpin, kedisiplinan seorang pemimpin mencerminkan keteladanan nya untuk unit-unit yang disupervisi olehnya. Atau menjadi roll model karyawannya. Begitu pun keteladanan di BTN Syariah mengacu kepada kedisiplinan pemimpin, dimana pemimpin adalah orang yang pertama mampu menjadi panutan dalam memberikan keteladanan kebaikan, saat bekerja mampu mengarahkan, memantau, mengawasi serta mengevaluasi secara proporsional, bagian yang dipimpinnya agar berpijak pada kaidah yang benar untuk meraih sukses bersama.

2. Perbedaan Antara BNI Syariah dan BTN Syariah

Pertama, pada kedisiplinan yang dapat membentuk keteladanan. Kedisiplinan yang dapat membentuk keteladanan BNI Syariah Yaitu kedisiplinan yang dapat membentuk karakter seorang karyawan bank sayariah sehingga menjadi orang yang teladan, seperti tepat waktu saat masuk bekerja, shalat tepat waktu, dan disiplin saat bekerja sehingga menjadi contoh untuk karyawan lain. Sedangkan kedisiplinan yang dapat membentuk keteladanan BTN Syariah Yaitu kedisiplinan yang dapat meningkatkan kualitas SDM Bank BTN 
Syariah. disiplin terhadap waktu dengan tidak terlambat masuk kerja, tidak melanggar peraturan jam isriharat, dan jadwal kerja lainnya. disiplin dalam bekerja seperti melaksanakan tugas dengan baik dan tepat waktu.

Kedua, perbandingan yang dapat membedakan kedisiplinan BNI Syariah dengan Bank Syariah lainnya yaitu BNI Syariah memiliki kebijakan yang berbeda dengan bank syariah lain. Contoh ketika hari Jum'at karyawan Bank BNI Syariah mengenakan pakaian baju Koko karena itu hari Jum'at sebagai bukti menghormati Agama, BNI Syariah jam layanan tutup 15 menit ketika waktu Shalat karena wajib shalat berjamaah dan tepat waktu, dan BNI Syariah memiliki angaran khusus setiap bulannya untuk mengisi kajian bulanan dan setiap bulan harus melaksanakan kajian dan itu sudah difasilitasi oleh kantor. Sedangkan yang dapat membedakan kedisiplinan BTN Syariah dengan Bank Syariah lainnya yaitu setiap jum'at sore pukul $17.00 \mathrm{~s} / \mathrm{d} 18.00 \mathrm{WIB}$ adalah forum diskusi untuk membahas produk dan SOP, kemudian setiap awal bulan dilakukan tes, dan terpilihlah pegawai dengan nilai tertinggi dan terendah. English day setiap hari jum'at dalam rangka persiapan menuju World class company. Silaturahmi atau pengajian bulanan ke rumah pegawai House to house, mengadakan Customer gathering dengan para nasabah, dan yang terakhir kegiatan spiritual rutin untuk seluruh pegawai yaitu shalat berjamaah.

\section{KESIMPULAN DAN SARAN}

\section{Kesimpulan}

Setelah melakukan penelitian mengenai perbandingan penerapan kode etik syariah di lembaga keuangan syariah (studi pada Bank BNI Syariah dan BTN Syariah), terdapat beberapa kesimpulan dan saran, sebagai berikut:

1. Penerapan kode etik syariah yang ada di BNI Syariah ditinjau dari etika umum, etika bisnis, kepatuhan Syariah dan keteladanan yaitu merupakan norma, pedoman dan aturan yang dimiliki oleh BNI Syariah yang menjadi landasan dalam berperilaku bagi setiap Insan BNI Syariah. Segenap Insan BNI Syariah diharuskan untuk mematuhi dan menerapkan setiap poin dari Etika Insan BNI Syariah sesuai dengan SE Direksi No. BNISy/DIR.403 tanggal 23 Desember 2010. Penerapan kode etik syariah yang ada di BTN Syariah hampir sama dengan yang ada di BNI Syariah, hanya saja memiliki sistem yang berbeda. Pada penerapan etika umum bank BTN Syariah memiliki point etika lebih sedikit dibandingkan dengan BNI Syariah yang menerapkan sembilan belas point etika. Pada penerapan etika bisnis keunggulan penerapan etika bisnis di BTN Syariah adalah loyal community pada perumahanperumahan yang dibiayai oleh bank BTN Syariah.

2. Berdasarkan hasil analisis, Bank BNI Syariah dan BTN Syariah memiliki perbedaan dalam penerapan kode etiknya di tinjau dari empat aspek yaitu etika umum, etika bisnis, kepatuhan syariah dan keteladanan hal ini dikarenakan kebijakan setiap Bank berbeda dan memiliki sistem kode etik yang berbeda. Namun bank BNI Syariah dan BTN Syariah memiliki juga persamaan pada penerapan etika syariah nya dimana Bank Syariah berlandaskan pada prinsip-prinsip Syariah (Islam).

\section{Saran}

Setelah melakukan penelitian mengenai perbandingan penerapan kode etik syariah di lembaga keuangan syariah (studi pada Bank BNI Syariah dan BTN 
Syariah), ada beberapa saran yang penulis sampaikan diantaranya :

1. Lembaga keuangan syariah khususnya Bank BNI Syariah dan BTN Syariah perlu adanya ketegasan dalam penerapan kode etiknya agar tidak terjadi pelanggaran yang dilakukan oleh karyawan. Terlebih lagi karyawan bank diharapkan dapat memperdalam pengetahuan mengenai kode etik yang bervariatif.

2. Penelitian ini menggunakan data dari hasil wawancara dan kode etik yang ada untuk membandingkan kedua Bank, untuk penelitian selanjutnya diharapkan untuk melakukan penelitian mengenai kode etik yang lebih luas Dan mendalam pada bank syariah ditinjau dari Hukum Islamlnya.

\section{DAFTAR PUSTAKA}

\section{Jurnal:}

Astuti, T. \& Khanifah. (2007). Analisis Perbedaan Persepsi Terhadap Kode Etik Akuntan Antara Akuntan Publik dan Akuntan Pemerintah (Studi Empiris Pada Kantor Publik Se-Kota Semarang \& Kantor Perwakilan BPKP Propinsi Jawa Tengah). Jurnal Ekonomi dan Bisnis. Volume 2, No.3, April.

Bhinga, P. \& Jesica, H. (2011). Pengaruh Kode Etik Profesi Akuntan Publik Terhadap Kualitas Auditor Independen Di Surabaya. Jurnal Akuntansi Kontemporer. Volume 3, No.1, Januari.

Cecylia, D. S. W (2012). Sikap Profesionalisme Dan Kode Etik Auditor Internal. Berkala Ilmiah Mahasiswa Akuntansi. Volume 1, No 3, Mei.

Ekawati, R. N. (2017). Studi Eksplorasi Penerapan Etika Bisnis Pada Perbankan Syariah di Indonesia. Jurnal Kajian Ekonomi dan Bisnis Islam. Vol. 10 No.1
Fadjarini, S. (2004). Organisasi Profesi Jurnalis Dan Kode Etik Jurnalistik. Jurnal Ilmu Komunikasi. Volume 1, No.1, Juni: 113-126.

Gunawan, A. (2010). Analisis Pengaruh Etika Kerja Islam Terhadap Komitmen Organisasi Dengan Komitmen Profesi Sebagai Variabel Intervening (Studi Empiris Terhadap Internal Auditor Bank di Jawa Tengah). Jurnal Pemikiran dan Penelitian Ekonomi Islam. Nomor II/ Edisi II/ November.

Ida, Edi. 2014. "Pengaruh Independensi, Due Profesional Care Dan Kepatuhan Pada Kode Etik Terhadap Kualitas Hasil Pemeriksaan Audit" Jurnal Akuntansi Program S1. Vol.2 No.1

Irfan. (2008). Persepsi Akuntan Intern Tentang Etika Bisnis (Studi Empiris Pada Perbankan di Simatra Utara). Jurnal Riset Akuntansi dan Bisnis. Vol.8 No.1/Maret

Iskandar. (2004). Peranan Etika Bisnis dalam Pembangunan Akhlak Mulia. Vol. XXIII No.1, Januari-Maret :5871

M. Fajar. (2003). Lembaga Keuangan Syariah dan Arbitrase Muamalat Indonesia. Al-Mawarid. Edisi $\mathrm{X}$ Tahun 2003

\section{Skripsi:}

Mardiana. (2017). Peran Serta Dan Mekanisme Bank Syariah Pada Pembiayaan Sindikasi (Studi Pada Bank Syariah Mandiri Pusat).

\section{Buku:}

Abdul, A'la Al-Maududy. (1993). Kode Etik Pergerakan Islam. Penerjemah: Katur Suhardi, Solo: Purimedia.

Abdurrahman, An-Nahlawi. (1995) pendidikan Islam di Rumah, Sekolah dan Masyarakat. Terjemah: Shihabuddin, Jakarta: Gema Insani.

Agoes, Sukrisno dan I Cenik Ardana. 2009. Etika Bisnis dan Profesi: 
Tantangan Membangun Manusia Seutuhnya. Jakarta: Salemba Empat Agoes, Soekrisno. 1996. Penegakan Kode Etik Akuntan Indonesia. Prosiding Konvensi Nasional Akuntansi ke-3, Memantapkan Posisi dan Peran Profesi Akuntansi dalam Lingkungan yang Berubah, Jakarta: IAI

Bertens, K. 2004 Pengantar Etika Bisnis. Yogyakarta: Kanisius.

Dr. Abd. Haris (2010). Etika Hamka. Yogyakarta: LKiS Printing Cemerlang.

Farhan, Djuni. (2009). Etika dan Akuntabilitas Profesi Akuntan Publik. Malang: Intimedia.

Feby, R. P. (n.d.). Perbandingan Sensitivitas Etis Account Officer Bamk Umum Konvensional dan Bank Umum Syariah di Kota Surabaya.

Hamzah, B. Uno. (2006). Orientasi Baru dalam Psikologi Pembelajaran. Jakarta: Bumi Aksara.

Ludigdo, U. (2007). Paradoks Etika Akuntan. Yogyakarta: Pustaka Pelajar.

Muhammad, D. (2008). Asas-asas Hukum Perbankan di Indonesia. Citra Aditya Bakti, Bandung.

Ngatiya. (n.d.). Penegakan Hukum Kode Etik Profesi Porli Terhadap Anggota Polri Yang Melakukan Tindak Pidana (Studi Pada Polresta Pontianak).
Noer, Rosita, Menggugah Etika Bisnis Orde Baru, Jakarta: Pustaka Sinar Harapan, 1998.

Qardhawi, Yusuf, Dawr al-Qiyam wa alAkhlaq fi al -Iqtisad al-Islami. Diterjemahkan oleh Zaibal Arifin dan Dahlia Husim, Norma dan Etika Ekonomi Islam, Cet. Ke-4; Jakarta: Gema Insani Press, 1422 H/2001 M.

Rafik Issa Beekum. (2004). Etika Bisnis Islam. Penerjemah: Muhammad, Yogyakarta: Pustaka Belajar.

Sugiono. (2010). Memahami Penelitian Kualitatif. Bandung: CV Alfabeta.

Sulistiyono. (n.d.). Pelaksanaan Sanksi Pelanggaran Kode Etik Profesi Notaris Oleh Dewan Kehormatan Ikatan Notaris Indonesia Di Kabupaten Tanggerang.

Tim. (1990). Kamus Besar Bahasa Indoensia. Jakarta: Balai Pustaka.

Tim. (2008). Kamus Besar Bahasa Indoensia. Edisi Keempat, Jakarta: PT Gramedia.

Widyawati. Ardiani, I. S. (n.d.). Perbedaan Perspsi Akuntan Publik, Akuntan Pendidikan dan Mahasiswa Akuntan Terhadap Kode Etik Ikatan Akuntan Indonesia.

Yanius, R. (2013). Penyelesaian Pelanggaran Kode Etik Profesi Oleh Kepolisian Republik Indonesia. Lex Crimen Vol. II/No.2/ April-Juni.

Yususf Qardhawi. (2001). Norma dan Etika Ekonomi Islam. Penerjemah: Zainal Arifin, L c,dkk Jakarta: Gema Insani Press. 